The Comedy Studies Reader 

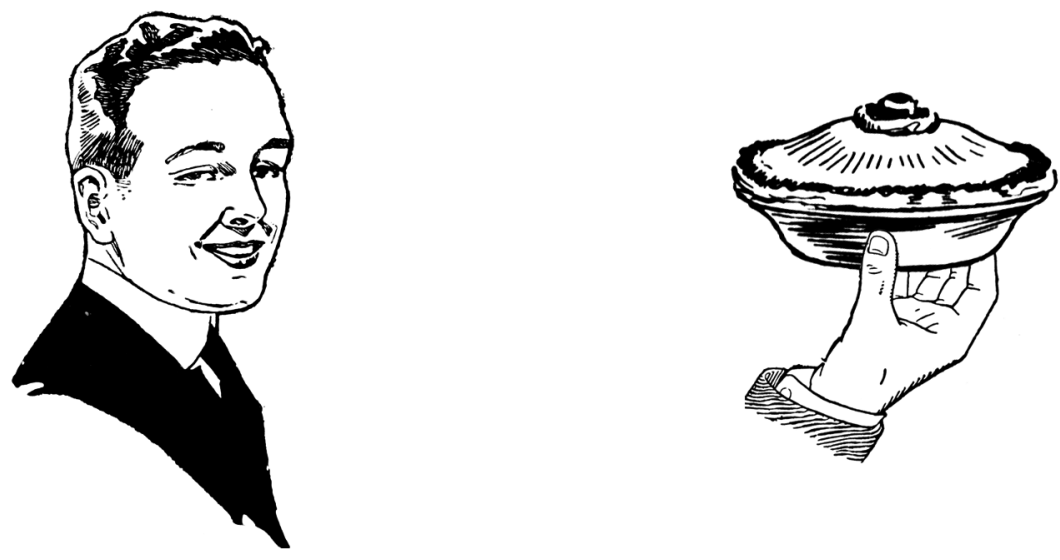

fig 1 .

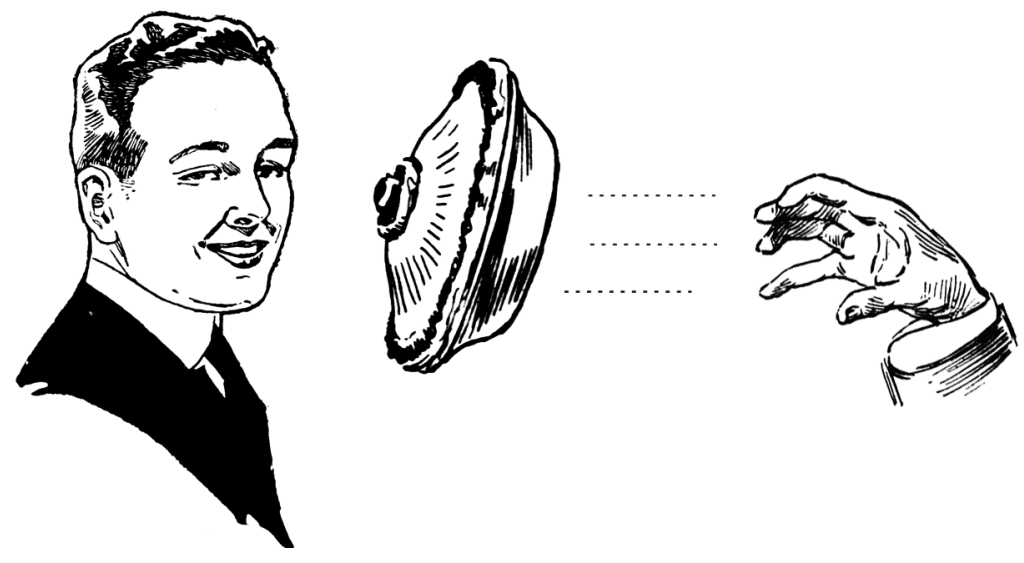

fig 2. 


\section{The Comedy Studies Reader}

EDITED BY NICK MARX \& MATT SIENKIEWICZ

University of Texas Press 
Copyright $\odot 2018$ by the University of Texas Press

All rights reserved

Printed in the United States of America

First edition, 2018

Requests for permission to reproduce material from this work should be sent to: Permissions

University of Texas Press

P.O. Box 7819

Austin, TX 787 13-7819

utpress.utexas.edu/rp-form

(0) The paper used in this book meets the minimum requirements of ANSI/NISO Z39.48-I992 (RI997) (Permanence of Paper).

\section{Library of Congress Cataloging-in-Publication Data}

Names: Marx, Nick, editor. I Sienkiewicz, Matt, editor.

Title: The comedy studies reader / edited by Nick Marx and Matt Sienkiewicz. Description: First edition. I Austin : University of Texas Press, 2018. I Includes bibliographical references and index.

Identifiers: LCCN 20I7046018

ISBN 978-I-4773-I599-6 (cloth : alk. paper)

ISBN 978-I-4773-I60o-9 (pbk. : alk. paper)

ISBN 978-I-4773-I6oI-6 (library e-book)

ISBN 978-I-4773-I602-3 (non-library e-book)

Subjects: LCsH: Comedy films - United States-History and criticism. I Television comedies-United States-History and criticism. I Popular culture-United States-History-2oth century. I Motion pictures-United States-2oth century. I Comedy-Social aspects-United States. I Comedy-History-2oth century.

Classification: LCC PNI995.9.C55 C664 2018 I DDC 791.43/617-dc23

LC record available at https://lccn.loc.gov/20170460I8

doi:10.7560/315996 